accidents in Great Britain than elsewhere. The electrical industry is one of the few major industries which has remained active during the past fow years. Em. ployment on the supply side increased by 50 per cent between 1924 and 1930. Notwithstanding this increase in the number of employees the number of fatalities remains practically the same. It is well for employers and occupiers to remember the law as recently laid down in High Court decisions that it is their duty to protect the workmen against their own errors, and it may be their own folly. It is not sufficient merely to give a warning. Although trade depression has been acute, the re-equipment of textile mills has been steadily progressing and the applications of electricity in factories is still increasing. Foreign firms have started branches in Great Britain which are fully equipped electrically. Luminous tubes are coming rapidly into use and although their manufacture involves high pressure, there is almost a complete absence of accidents. Several accidents from severe shock have been reported where the prompt use of artificial respiration probably saved the injured persons' lives.

\section{History and Development of Electric Power}

THe history and development of electric power has recently been reviewed in a handbook by W. T. O'Dea (South Kensington, Science Museum Handbooks. "Electric Power", Part I, "History and Development". London: H.M. Stationery Office, 1933. $2 s$. net). This handbook should prove of the greatest value to inventors of electrical devices. An excellent historical account is given of the development of the various sections of the electrical industry. Notable apparatus illustrating the various stages in the development of the art and represented in the Museum by originals or replicas are indicated by asterisks. Anyone therefore who has read this book beforehand will be able to derive the full benefit from a visit to the Museum. Clearly printed photographs are shown illustrating the latest devices and methods used in engineering; they include a mercury arc rectifier, high-tension lattice towers, methods of transporting heavy engineering apparatus, etc. Many of the objects exhibited at the Faraday centenary exhibition are now included.

\section{Fishes of the Thames Estuary}

Is the Southend Standard of August 24, Mr. A. Laurence Wells writes a very interesting article based on further notes from Dr. Murie's work on the Leigh fisheries. This includes a list of all fishes recorded from the Thames estuary with remarks on each species. Considerable changes have occurred in the fish fauna during the last fow centuries. Long ago salmon were abundant, coming up the river to breed ; after 1833 none were seen, the pollution of the river cutting them off from their favourite haunts. Now they are returning since the conditions have been much improved. The salmon trout was far commoner in Elizabethan days than at the present time although a few may still be taken. The smelt fishery used to be much more important than it is now. The Thames sturgeon was celebrated in former years and is still fairly common in the estuary. Some fishes come for breeding purposes, others occur only as iry, many are permanent inhabitants or regular seasonal visitors. The herring in late summer forms 80 per cent of the whitebait; there are no less than fifteen species of the flat-fish family, eleven of the cod family and six of the herring family, whilst almost every group of fishes is represented. Rarities include specimens of the sword-fish, the pilot-fish and the flying-fish.

\section{Medical Census of Nigeria}

We have received two volumes of the medical census of Nigeria, vol. 5, Northern Provinces by Dr. R. C. Jones, and vol. 6, Southern Provinces by Dr. J. G. S. Turner ("Census of Nigeria, 1931". Crown Agents for the Colonies, 1932. 4 Millbank, London, S.W.1. Price 7s. and 8s, respectively). Attention is directed to the difficulties of obtaining reliable data in a native population, so that the results are approximate only. Details are given of the climate, sanitation, and social customs of the districts. The percentage of males and females at all ages are approximately the same. Children are welcome, and the birth-rate is high, 40-55 per 1,000. As might be expected, the infant mortality rate is high, as much as 250-350 per 1,000 births. Smallpox is prevalent, and in some districts more than half the population have suffered attack. The percentage vaccinated varies much, from scarcely any in some areas to 90 in other areas. Malaria is hyperendemic and there is some leprosy. A note on the covers of the volumes of the census states that an insecticide has been used in the binding so as to render them impervious to the ravages of insects.

\section{Recent Earthquakes in China}

Between August 23 and 31, a series of destructive earthquakes occurred in the northern part of the province of Szechuan. In the valley of the Min, a tributary of the Yangtze, great damage was caused in the portion between Sungtan and Mowchow. According to a message in the Times for September 20, the earthquake was accompanied by a sudden upheaval of the bed of the Min, by which its waters were made to flow upstream. One member of the series was probably that recorded at West Bromwich on August 25, the greatest registered there during the last six months. In past times, and especially just before and after the beginning of the Christian era, the province was frequently visited by destructive earthquakes that gave rise to many landslips among the mountains. On two occasions, in 26 and 10 B.C., these landslips obstructed the flow of the River Min.

\section{Empire Marketing Board's Film Library and Cinema}

A SIDE-LINE of the activities of the Empire Marketing Board, which came to an end on September 30, was the collection of a valuable library of instructional films and the maintenance of a cinema at the Imperial Institute. A few days ago it was announced that the 